\title{
The exotic wasp Megastigmus transvaalensis (Hymenoptera: Torymidae): first record and damage on the Brazilian peppertree, Schinus terebinthifolius drupes, in São Paulo, Brazil
}

\author{
PEDRO J. FERREIRA-FILHO ${ }^{1}$, FÁTIMA C.M. PIÑA-RODRIGUES ${ }^{1}$, JOSÉ M.S. SILVA ${ }^{1}$, JULIO C. GUERREIRO ${ }^{2}$, \\ THAÍS C. GHIOTTO ${ }^{1}$, IVONIR PIOTROWSKI ${ }^{1}$, LUIZ P. DIAS ${ }^{1}$, CARLOS F. WILCKEN ${ }^{3}$ and JOSÉ C. ZANUNCIO ${ }^{4}$
}

\author{
${ }^{1}$ Departamento de Ciências Ambientais, Universidade Federal de São Carlos, Rodovia João Leme \\ dos Santos, Km 110, SP-264, s/n, Bairro do Itinga, 18052-780 Sorocaba, SP, Brasil \\ ${ }^{2}$ Centro de Ciências Agrárias, Universidade Estadual de Maringá, Estrada da Paca, \\ s/n, Bairro São Cristóvão, 87507-190 Umuarama, PR, Brasil \\ ${ }^{3}$ Departamento de Proteção Vegetal, Faculdade de Ciências Agronômicas, Universidade Estadual Paulista, Campus de \\ Botucatu, Fazenda Experimental Lageado, Rua José Barbosa de Barros, 1780, 18610-307 Botucatu, SP, Brasil \\ ${ }^{4}$ Departamento de Entomologia, Universidade Federal de Viçosa, Campus \\ Universitário, Av. P. H. Rolf, s/n, 36570-900 Viçosa, MG, Brasil
}

Manuscript received on September 26, 2014; accepted for publication on February 9, 2015

\begin{abstract}
This paper records the first report of Megastigmus transvaalensis Hussey (Hymenoptera: Torymidae) in Brazilian peppertree, Schinus terebinthifolius Raddi (Anacardiaceae) drupes in Sorocaba, state of São Paulo, Brazil. This wasp is an invasive species and was found damaging S. terebinthifolius drupes in urban areas $(35.0 \pm 15.8 \%)$, natural forests $(21.5 \pm 10.2 \%)$ and restoration areas $(15.8 \pm 8.4 \%)$. The bioecology and damage caused by $M$. transvaalensis in the $S$. terebinthifolius drupes warrants further study focused upon the management of this phytophagous wasp. Megastigmus transvaalensis has a potential to be disseminated throughout Brazil and is posing a threat to the natural regeneration of S. terebinthifolius in the native forests and restoration areas and ecological regions of this country.
\end{abstract}

Key words: Anacardiaceae, biological control, forest pest, monitoring, restoration.

\section{INTRODUCTION}

Brazilian peppertree, Schinus terebinthifolius Raddi (Anacardiaceae), native to Brazil, Paraguay and Argentina (Ewel et al. 1982), is a pioneer plant (Lenzi and Orth 2004a) of tropical and subtropical regions (McKay et al. 2009). This species has been introduced in more than 20 countries (Morton 1978, Mytinger and Williamson 1987) and is considered

Correspondence to: Pedro José Ferreira-Filho

E-mail: pedrojf@ufscar.br invasive in USA (Ewel 1986, Habeck 1995). In Brazil, S. terebinthifolius occurs from the coast to inland areas at altitudes up to 2000 feet in the state of Pernambuco and in southern Brazil (Joly 1979, Lenzi and Orth 2004a). This dioecious plant, pollinated by Diptera and Hymenoptera (Lenzi and Orth 2004b), can adapt to different areas reaching up to 5-6 meters in height (Lenzi and Orth 2004a) in the sandy and clayey soils of the Atlantic Forest. Furthermore, it grows in the sandbank soils (Cesário and Gaglianone 2008, Lenzi and 
Orth 2004b) and regenerating regions, fringes of the forests, cities, swamps and pastures (Ewe and Sternberg 2002, Tassin et al. 2007). Schinus terebinthifolius tolerates extreme conditions of humidity, shaded environments and saline conditions (Cuda et al. 2005) with rapid growth and allelopathic compounds (Morgan and Overholt 2005 ) in locations where other species present less growth (Donnelly et al. 2008). This plant is regarded as invasive in many countries; however, in Brazil it is recommended for land reclamation (José et al. 2005) due to its pioneering behavior, attractiveness to birds (Panetta and McKee 1997, Hight et al. 2002, D'Avila et al. 2010) and good development in less fertile soils (Souza et al. 2001).

A phytophagous wasp was first noted in 2012 damaging the $S$. terebinthifolius drupes in the Sorocaba municipality $\left(23^{\circ} 30^{\prime} \mathrm{S}\right.$ and $\left.47^{\circ} 25^{\prime} \mathrm{W}\right)$ in the state of São Paulo State, Brazil. During the dry season, from July-August 2014, three branches with drupes were collected using pruning shears at the lower third of each one of the 25 trees of this plant in three zones: a native semidecidual seasonal forest, a restored site and an urban forest (Table I), and stored in paper bags. Hundreds of S. terebinthifolius drupes were randomly sampled from the three branches per tree and placed in 500 $\mathrm{ml}$ transparent plastic containers with lids, and maintained at $25{ }^{\circ} \mathrm{C}$ with white light along $16 \mathrm{~h}$ to force the hatching of insects. After that, the number of emergence holes on the drupes and the number of adult insects were counted utilizing a stereoscopic microscope with 10 fold magnification (Figs. 1 and 2). A Kruskall-Wallis analysis and Tukey's test $(P \leq 0.05)$ were performed to compare drupe damages (DD) among trees and sites.

The phytophagous wasps were identified as Megastigmus transvaalensis Hussey 1956 (Hymenoptera: Torymidae) by Dr. Paul Hanson of the University of Costa Rica, University City, School of Biology, San Pedro, Costa Rica.
TABLE I

Number $\left(\mathrm{N}^{\circ}\right)$, location of trees (Geog. coord.) and percentage of Schinus terebinthifolius drupes damaged (\%DD) (mean \pm SD) by Megastigmus transvaalensis (Hymenoptera: Torymidae) in the semidecidual seasonal natural forests (Forest), restoration areas (Restoration) and urban areas (Afforestation) in Sorocaba, São Paulo, Brazil.

\begin{tabular}{|c|c|c|}
\hline $\mathrm{N}^{\circ}$ & Geog. coord. & $\% \mathrm{DD}$ \\
\hline \multicolumn{3}{|c|}{ Forest } \\
\hline 1 & $23^{\circ} 35.20^{\prime} \mathrm{S} \quad 47^{\circ} 31.12^{\prime} \mathrm{W}$ & 35 \\
\hline 2 & $23^{\circ} 35.21^{\prime} \mathrm{S} \quad 47^{\circ} 31.13^{\prime} \mathrm{W}$ & 28 \\
\hline 3 & $23^{\circ} 35.20^{\prime} \mathrm{S} \quad 47^{\circ} 31.14^{\prime} \mathrm{W}$ & 21 \\
\hline 4 & $23^{\circ} 35.21^{\prime} \mathrm{S} \quad 47^{\circ} 31.15^{\prime} \mathrm{W}$ & 31 \\
\hline 5 & $23^{\circ} 35.14^{\prime} \mathrm{S} \quad 47^{\circ} 30.99^{\prime} \mathrm{W}$ & 23 \\
\hline 6 & $23^{\circ} 35.15^{\prime} \mathrm{S} \quad 47^{\circ} 31.31^{\prime} \mathrm{W}$ & 12 \\
\hline 7 & $23^{\circ} 34.97^{\prime} \mathrm{S} \quad 47^{\circ} 31.31^{\prime} \mathrm{W}$ & 1 \\
\hline 8 & $23^{\circ} 35.12^{\prime} \mathrm{S} \quad 47^{\circ} 31.48^{\prime} \mathrm{W}$ & 29 \\
\hline 9 & $23^{\circ} 34.99^{\prime} \mathrm{S} \quad 47^{\circ} 31.62^{\prime} \mathrm{W}$ & 21 \\
\hline \multirow[t]{2}{*}{10} & $23^{\circ} 35.00^{\prime} \mathrm{S} \quad 47^{\circ} 31.61^{\prime} \mathrm{W}$ & 14 \\
\hline & Mean \pm SD $(\%)$ & $21.5 \pm(10.2)$ \\
\hline \multicolumn{3}{|c|}{ Restoration } \\
\hline 11 & $23^{\circ} 21.94^{\prime} \mathrm{S} \quad 47^{\circ} 28.65^{\prime} \mathrm{W}$ & 9 \\
\hline 12 & $23^{\circ} 21.95^{\prime} \mathrm{S} \quad 47^{\circ} 28.66^{\prime} \mathrm{W}$ & 12 \\
\hline 13 & $23^{\circ} 21.96^{\prime} \mathrm{S} \quad 47^{\circ} 28.66^{\prime} \mathrm{W}$ & 14 \\
\hline 14 & $23^{\circ} 21.92^{\prime} \mathrm{S} \quad 47^{\circ} 28.56^{\prime} \mathrm{W}$ & 20 \\
\hline 15 & $23^{\circ} 21.90^{\prime} \mathrm{S} \quad 47^{\circ} 28.60^{\prime} \mathrm{W}$ & 5 \\
\hline 16 & $23^{\circ} 21.95^{\prime} \mathrm{S} \quad 47^{\circ} 28.45^{\prime} \mathrm{W}$ & 29 \\
\hline 17 & $23^{\circ} 21.97^{\prime} \mathrm{S} \quad 47^{\circ} 28.42^{\prime} \mathrm{W}$ & 12 \\
\hline 18 & $23^{\circ} 22.14^{\prime} \mathrm{S} \quad 47^{\circ} 27.78^{\prime} \mathrm{W}$ & 13 \\
\hline 19 & $23^{\circ} 22.12^{\prime} \mathrm{S} \quad 47^{\circ} 27.84^{\prime} \mathrm{W}$ & 31 \\
\hline \multirow[t]{2}{*}{20} & $23^{\circ} 22.07^{\prime} \mathrm{S} \quad 47^{\circ} 27.99^{\prime} \mathrm{W}$ & 13 \\
\hline & Mean \pm SD $(\%)$ & $15.8 \pm(8.4)$ \\
\hline \multicolumn{3}{|c|}{ Afforestation } \\
\hline 21 & $23^{\circ} 31.77^{\prime} \mathrm{S} \quad 47^{\circ} 28.11^{\prime} \mathrm{W}$ & 55 \\
\hline 22 & $23^{\circ} 31.58^{\prime} \mathrm{S} \quad 47^{\circ} 28.16^{\prime} \mathrm{W}$ & 44 \\
\hline 23 & $23^{\circ} 31.48^{\prime} \mathrm{S} \quad 47^{\circ} 28.12^{\prime} \mathrm{W}$ & 36 \\
\hline 24 & $23^{\circ} 31.43^{\prime} \mathrm{S} \quad 47^{\circ} 28.05^{\prime} \mathrm{W}$ & 26 \\
\hline \multirow[t]{3}{*}{25} & $23^{\circ} 31.43^{\prime} \mathrm{S} \quad 47^{\circ} 28.03^{\prime} \mathrm{W}$ & 14 \\
\hline & Mean \pm SD $(\%)$ & $35.0 \pm(15.8)$ \\
\hline & & CV\% \\
\hline $\begin{array}{c}\text { Trees } \\
\text { Mean } \pm \text { SD } \\
(\%)\end{array}$ & $21.9 \pm(12.6)$ & 57.5 \\
\hline $\begin{array}{c}\text { Sites } \\
\text { Mean } \pm \text { SD } \\
(\%)\end{array}$ & $24.1 \pm(3.4)$ & 15.6 \\
\hline
\end{tabular}




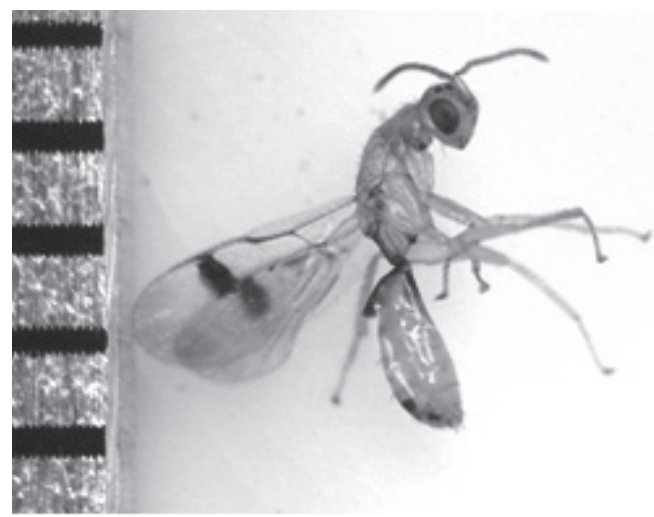

(a)

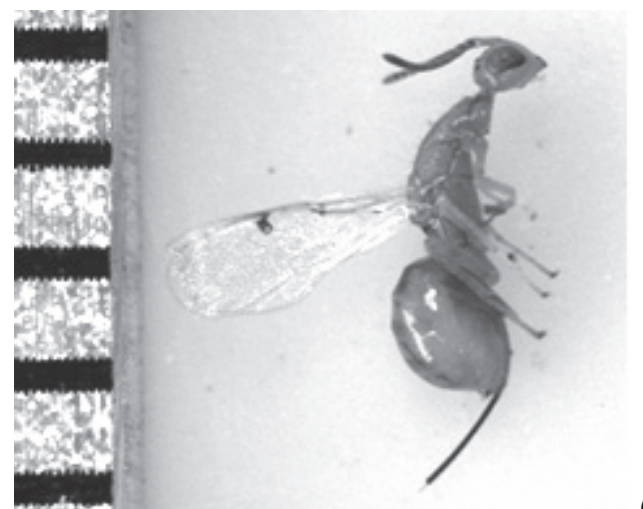

(b)

Figure 1 - Megastigmus transvaalensis (Hymenoptera: Torymidae) adults emerged from Schinus terebinthifolius drupes. Side view of a male (a) and female (b). Scale bars in millimeters.

Although Schinus spp. are native South American tree species, the wasp $M$. transvaalensis is presumed to originate from South Africa (Scheffer and Grissell 2003). It was also reported from the Canary Islands (Grissell 1979), Mauritius and USA (Habeck et al. 1989), Argentina (Wheeler et al. 2001), state of Paraná, Brazil (Perioto 1999), Southern Europe (Continental France and Corsica, Portugal and Continental Spain) and North Africa (Morocco) (Roques and Skrzypczynska 2003). Actually, the seed chalcid is capable of developing and reproducing on plants in the genera Rhus and Schinus. The host range includes at least three Rhus spp. in South Africa of which Rhus laevigata L. and R. angustifolia L. (Hussey 1956, Grissell 1979, Yoshioka and Markin 1991), and Schinus molle L. and $S$. terebinthifolius, which are both native to South America (Hussey 1956, Habeck et al. 1989).

Adults of Megastigmus transvaalensis are yellowish-brown in color, with males and females measuring 2.3 to $2.9 \mathrm{~mm}$ and 3.1 to $3.4 \mathrm{~mm}$ in length, respectively (Fig. 1). Female ovipositor reaches about half of the body length (Hussey 1956). In most Megastigmus species, egg incubation period is short, the first-instar larvae hatching after four to five days. The larvae then develop through five successive instars to pupae, which are often capable of prolonged diapause (Milliron 1949). Wasps lay more than one egg per $S$. terebinthifolius drupe but larvae are cannibalistics and after several months, we observed that only an adult emerges from each $S$. terebinthifolius drupe, leaving a quite circular exit hole (Fig. 2).

Megastigmus transvaalensis damaged 1-55\% of $S$. terebinthifolius drupes collected per tree in the state of São Paulo, Brazil with greater variation than that reported in Florida, USA, where 31\% and $76 \%$ of them were damaged in the winter and spring, respectively (Wheeler et al. 2001) and $80 \%$ in Hawaii (Hight et al. 2003). Furthermore, damage largely varied among trees $(\mathrm{cv}=57.5 \%)$ and sites $(\mathrm{cv}=15.6 \%)$ (Table I). Drupe damage also differed significantly between zones (KruskallWallis test; $\mathrm{H}=6.927 ; P=0.031)$. Following Tukey test, it appeared that damage did not differ between urban areas $(35.0 \pm 15.8 \%)$ and natural forests $(21.5 \pm 10.2 \%)$ but restoration areas $(15.8 \pm 8.4 \%)$ were significantly less attacked than urban areas (Table I).

The observed number of damaged caused by $M$. transvaalensis to the $S$. terebinthifolius drupes is only an indicator, and the damage may be more important if empty seeds are considered and therefore, requires further study in Brazil. Monitoring of this wasp is necessary for proper population management to lessen the damage it causes to the $S$. terebinthifolius drupes and others Anacardiaceae species. 

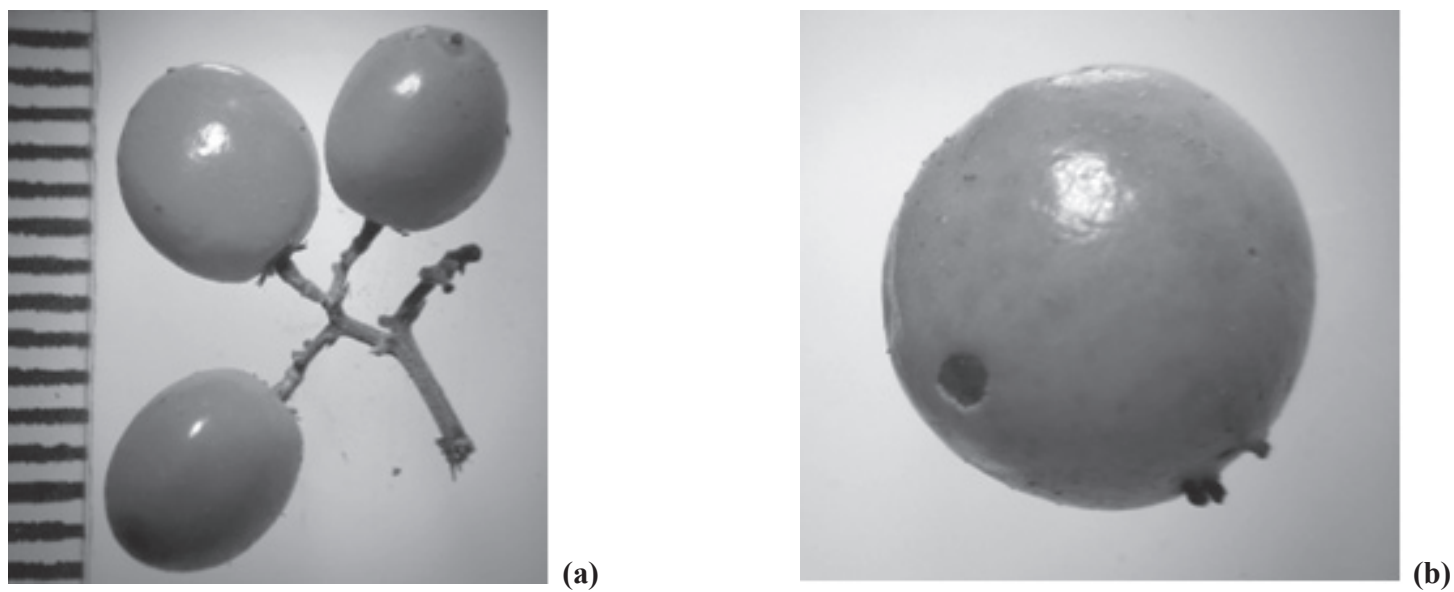

Figure 2 - Undamaged Schinus terebinthifolius (Anacardiaceae) drupes (a) and drupe with the circular exit hole (b) of Megastigmus transvaalensis (Hymenoptera: Torymidae) adults. Scale bars in millimeters.

\section{ACKNOWLEDGMENTS}

To Conselho Nacional de Desenvolvimento Científico e Tecnológico (CNPq), Coordenação de Aperfeiçoamento de Pessoal de Nível Superior (CAPES) and Fundação de Amparo à Pesquisa do Estado de Minas Gerais (FAPEMIG) for financial support. The authors express sincere thanks to Dr. Paul Hanson from the Universidad de Costa Rica Ciudad Universitaria, Escuela de Biologia, San Pedro, Costa Rica for assistance in identification of the species studied. Global Edico Services corrected and edited the English of this manuscript.

\section{RESUMO}

Este trabalho registra o primeiro relato de Megastigmus transvaalensis Hussey (Hymenoptera: Torymidae) em drupas de aroeira-vermelha brasileira, Schinus terebinthifolius Raddi (Anacardiaceae), em Sorocaba, estado de São Paulo, Brasil. Essa vespa é uma espécie invasora e foi encontrada danificando drupas de $S$. terebinthifolius em áreas urbanas $(35,0 \pm 15,8 \%)$, florestas nativas $(21,5 \pm 10,2 \%)$ e áreas de restauração $(15,8 \pm 8,4 \%)$. A bioecologia e os danos causados por $M$. transvaalensis em drupas de $S$. terebinthifolius justificam mais estudos visando o manejo dessa vespa fitófaga. Megastigmus transvaalensis tem um potencial de ser disseminado por todo Brasil e representa uma ameaça para a regeneração natural de $S$. terebinthifolius em florestas nativas e áreas de recomposição e restauração ecológica do país.

Palavras-chave: Anacardiaceae, controle biológico, praga florestal, monitoramento, restauração.

\section{REFERENCES}

CESÁRIO LF AND GAGLIANONE MC. 2008. Biologia floral e fenologia reprodutiva de Schinus terebinthifolius Raddi (Anacardiaceae) em restinga do Norte Fluminense. Acta Bot Bras 22: 828-833.

CUdA JP, MEDAL JC, VitORINO MD AND HABECK DH. 2005. Supplementary host specificity testing of the sawfly Heteroperryia hubrichi, a candidate for classical biological control of Brazilian peppertree, Schinus terebinthifolius, in the USA. BioControl 50: 195-201.

D'Avila G, GOMES JR A, CANARY AC AND BUGONI L. 2010. The role of avian frugivores on germination and potential seed dispersal of the Brazilian pepper Schinus terebinthifolius. Biota Neotrop 10: 45-51.

DONNELly MJ, GREen DM AND WALTERS LJ. 2008. Allelopathic effects of fruits of the Brazilian pepper Schinus terebinthifolius on growth, leaf production and biomass of seedlings of the red mangrove Rhizophora mangle and the black mangrove Avicennia germinans. J Exp Marine Biol Ecol 357: 149-156.

EWE SML AND STERNBERG LSL. 2002. Seasonal water-use by the invasive exotic, Schinus terebinthifolius, in native and disturbed communities. Oecologia 133: 441-448.

EWEL J. 1986. Invasibility: Lessons from South Florida. In: Mooney HA and Drake JA (Eds), Ecology of biological invasions of North America and Hawaii, New York: Springer-Verlag, New York, USA, p. 214-230.

EWEL J, OJIMA DS, KARL DA AND DEBUSK WF. 1982. Schinus in successional ecosystems of Everglades 
National Park. South Florida Research Center Report No. T-676. National Park Service, Everglades National Park, Homestead, FL, 141 p.

GRISSELL EE. 1979. Subfamily Megastigminae. In: Krombein KV and Hurd HDJ (Eds), Catalog of Hymenoptera in American North of Mexico, Washington: Smithsonian Inst. Press, Washington, DC, USA, p. 765-767.

HABECK DH. 1995. Biological control of Brazilian peppertree. Fla Nature 68: 9-11.

HABECK DH, BENNETT FD AND GRISSELl EE. 1989. First record of a phytophagous seed chalcid from Brazilian peppertree in Florida. Fla Entomol 72: 378-379.

Hight SD, CUDA JP AND MEDAL JC. 2002. Brazilian peppertree. In: Van Driesche RG et al. (Eds), Biological control of invasive plants in the Eastern United States, Morgantown: USDA Forest Service, p. 311-321.

Hight SD, HORIUCHI I, VITORINO MD, WIKLER CW AND PEDROSA-MACEDO JH. 2003. Biology, host specificity tests, and risk assessment of the sawfly Heteroperreyia hubrichi, a potential biological control agent of Schinus terebinthifolius in Hawaii. BioControl 48: 461-476.

HUSSEY NW. 1956. A new genus of African Megastigminae (Hymenoptera: Chalcidoidea). Proc R Soc Lond B 25: 157-162.

JOLY AB. 1979. Botânica: Introdução à taxonomia vegetal. $2^{\mathrm{a}}$ ed., São Paulo: Companhia Editora Nacional, 505 p.

José AC, DAVIDE AC AND OLIVEIRA SL. 2005. Produção de mudas de aroeira (Schinus terebinthifolius Raddi) para recuperação de áreas degradadas pela mineração de bauxita. Cerne 11: 187-196.

LENZI M AND ORTH AI. 2004a. Caracterização funcional do sistema reprodutivo da aroeira-vermelha (Schinus terebinthifolius Raddi), em Florianópolis-SC, Brasil. Rev Bras Frutic 26: 198-201.

LENZI M AND ORTH AI. 2004b. Fenologia reprodutiva, morfologia e biologia floral de Schinus terebinthifolius Raddi (Anacardiaceae), em restinga da ilha de Santa Catarina, Brasil. Biotemas 17: 67-89.

MCKay F, Oleiro M, CABRERA GW, GANDOLFo D, CUdA JP AND WHEELER GS. 2009. Natural enemies of Brazilian peppertree (Sapindales: Anacardiaceae) from Argentina: their possible use for biological control in the USA. Fla Entomol 92: 292-303.

MILLIRON HE. 1949. Taxonomic and biological investigations in the genus Megastigmus with particular reference to the taxonomy of the Nearctic species (Hymenoptera: Chalcidoidea: Callimomidae). Am Midl Nat 41: 257-420.

MORGAN EC AND OVERHOLT WA. 2005. Potential allelopathic effects of Brazilian pepper (Schinus terebinthifolius Raddi, Anacardiaceae) aqueous extract on germination and growth of selected Florida native plants. J Torrey Bot Soc 132: $11-15$.

MORTON JF. 1978. Brazilian pepper - its impact on people, animals and the environment. Econ Bot 32: 353-359.

MYTINGER L AND WILLIAMSON GB. 1987. The invasion of Schinus into saline communities of Everglades National Park. Florida Sci 50: 7-12.

PANETTA D AND MCKEE J. 1997. Recruitment of the invasive ornamental, Schinus terebinthifolius, is dependent upon frugivore. Aust J Ecol 22: 432-438.

PERIOTO NW. 1999. First record of the genus Megastigmus Dalman, 1820 (Hymenoptera: Torymidae) and first record for the subfamily Megastigminae from Brazil. Arq Inst Biol 64: 115-116.

ROQUES A AND SKRZYPCZYNSKA M. 2003. Seed-infesting chalcids of the genus Megastigmus Dalman (Hymenoptera: Torymidae) native and introduced to Europe: taxonomy, host specificity and distribution. J Nat History 37: $127-$ 238.

SCHEFFER SL AND GRISSELL EE. 2003. Tracing the geographical origin of Megastigmus transvaalensis (Hymenoptera: Torymidae): an African wasp feeding on a South American plant in North America. Mol Ecol 12: 415-421.

Souza PA, Venturin N, Macedo RLG, Alvarenga MIN AND SILVA VF. 2001. Estabelecimento de espécies arbóreas em recuperação de área degradada pela extração de areia. Cerne 7: 43-52.

TASSIN J, RIVIÈRE JN AND CLERGEAU P. 2007. Reproductive versus vegetative recruitment of the invasive tree Schinus terebinthifolius: Implications for restoration on Reunion Island. Restor Ecol 15: 412-419.

WheELER GS, MASSEy LM AND ENDRIES M. 2001. The Brazilian peppertree drupe feeder Megastigmus transvaalensis (Hymenoptera: Torymidae): Florida distribution and impact. Biol Control 22: 139-148.

YOSHIOKA ER AND MARKIN GP. 1991. Efforts of biological control of Christmas berry (Schinus terebinthifolius) in Hawaii. In: Center TD et al. (Eds), Proceedings of the Symposium of Exotic Pest Plants, Miami, FL, U.S. Dept. Interior, National Park Service, Washington, DC, p. $377-$ 387. 
